DOI: $10.21802 /$ artm.2020.1.13.166.

УДК [616-08-059+615.825]:378.096

\title{
ОСОБЛИВОСТІ ВИКЛАДАННЯ МОДУЛЮ «ХІРУРГІЯ» 3 ВРАХУВАННЯМ ТЕОРІЇ ПОКОЛІНЬ STRAUSS-HOWE
}

\author{
С.С. Сніжко ${ }^{1}$, С.А. Кримець ${ }^{2}$ \\ ${ }^{1}$ Івано-Франківський національний медичний університет, кафедра хірургї̈ №2 та кардіохірургї, \\ м. Івано-Франківськ, Украӥна, \\ ORCID ID: 0000-0001-5418-7825,e-mail: snizhko.s@bigmir.net; \\ ${ }^{2}$ Івано-Франківський національний медичний університет, кафедра хірургіï №1, \\ м. Івано-Франківськ, Украӥна, \\ ORCID ID: 0000-0002-5098-5536,e-mail: skrymets80@gmail.com
}

Резюме. У статті викладені основні підходи до принципів навчання модулю «Хірургія» студентів медичних факультетів IV i V курсів вищих навчальних медичних закладів з позицій теорії поколінь StraussHowe. Сучасне викладання повинне враховувати психологічні особливості людей, які народилися після 1996 року: залежність від цифрових технологій та сприйняття інформації шляхом короткої і яскравої подачі. Сучасний студент володіє дуже корисними когнітивними навиками - це колосальна здатність до multitasking (мультизадачності). Специфіка роботи їхнього мозку - це висока швидкість, відмінна інтерактивність, здатність швидко грати в комп’ютерні ігри і повне несприйняття книг. Але multitasking повністю ослабив дві важливі речі, на яких базується класичне навчання: об’єм уваги і довгострокову пам'ять. Процес викладання такої практичної дисципліни як хірургія повинен базуватися на абсолютно нових підходах, відмінних від тих, які були 1020 років тому. Сучасний студент не зможе концентруватися, якщо подача навчального матеріалу викладачем $\epsilon$ одноманітною більше, ніж 10-15 хвилин. Головний шлях до мотивації покоління Z - за короткий період надати інформацію, в якій вони побачать очевидну практичну користь для себе. Під час лекції чи аудиторного заняття викладачу слід постійно створювати ідеальне співвідношення між часом подання інформації і її практичною цінністю. Подача клінічної інформації повинна вкластися в межах 5-7 хвилин і висвітлити основні пункти: паспортні дані, хірургічний діагноз, тактику і метод лікування у даному випадку. Викладач повинен враховувати соціальні і психологічні аспекти життя покоління Z і створювати гнучку індивідуалізовану систему викладання, абсолютно відмінну від тієї, за якою навчали його. Вона не завжди буде зручною для педагога, однак дозволить створити добрий комунікативний зв'язок між ним і студентами, що дозволить досягнути основної мети навчання.

Ключові слова: покоління Z, викладання, хірургія.

Вступ. Сучасний ритм життя суспільства, тотальна залежність від інтернету, соціальних мереж, електронних масмедіа вимагає нових підходів до викладання багатьох дисциплін у вищих навчальних закладах, у тому числі й хірургії. Засоби комунікації в певні періоди розвитку соціуму формують середовище, у якому розвивається і навчається людина. Це створює специфічні поведінкові реакції, мотивацію, особливості в досягненні мети тощо. Вперше «теорія поколінь» була створена американськими демографами N.Howe та W.Strauss у 1991 році [1]. На їхню думку, покоління - це група людей, що народилися в певний віковий період, підпали під вплив одних і тих же подій та особливостей виховання, що сформувало у них спільні цінності. Згідно 3 теорією поколінь Strauss-Howe, людей, які взаємодіють між собою у сучасному суспільстві, поділяють на п'ять груп: Silent Generation (мовчазне покоління) - народилися в період до 1942 року, Baby Boom Generation (покоління бебі-бум) - з 1943 до 1962 року, Generation X (покоління X) - з 1963 до 1983 року, Generation Y (покоління Y) - з 1984 до 1995 року та Generation Z (покоління Z) - з 1996 року.

Обгрунтування дослідження. Студенти, які в даний час навчаються на IV i V курсах медичних факультетів вищих навчальних закладів, відносяться до покоління $Z$ - це люди, які народилися після 1996 року. В основі їхнього пізнання соціуму чітко задіяні цифрові технології. Те, що для попередніх поколінь було фантастикою, для них є повсякденною реальністю. Вони вкрай залежні від цифрових технологій, на відміну від викладачів, які звикли отримувати знання 3 книг та наукових журналів (покоління X) [2]. Сучасні студенти майже всю інформацію отримують 3 інтернету. Якщо ми ставимо перед ними завдання ознайомитися, скажімо, з керівництвом 3 діагностики та лікування інтраабдомінальних інфекцій, найперше, що вони зроблять - розпочнуть пошук в інтернеті. Це покоління вміє чудово працювати 3 пошуком i аналізом потрібної інформації. Такий необмежений доступ до неї надає їм впевненості у своїх поглядах, вони доволі відкрито висловлюють свої погляди, що часто шокує покоління $\mathrm{X}$.

Мета дослідження: покращити викладання модулю «Хірургія» 3 врахуванням теорії поколінь strauss-howe.

Результати дослідження та їх обговорення. Покоління Z практично ніколи не розпочне інфор- 
маційний пошук у паперових носіях. Ми вимушені констатувати, що тиша й запах бібліотечних залів для них є невідомим і вкрай нудним заняттям. Вони є поколінням досвідчених споживачів, які знають, чого вони хочуть і як це отримати. Основною рисою сучасних студентів $€$ особливість їхнього мислення, сформована цифровими технологіями. Вони звикли сприймати інформацію шляхом короткої і яскравої подачі. Процес створення багатьох властивостей об'єктів без взаємозв'язку між ними, фрагментарність інформаційного потоку, алогічність та повна гетерогенія інформаційних даних без формування цілісної картини - є нормою для покоління Z [3].

Така особливість мислення сформувала дуже корисні когнітивні навики, які, на жаль, відсутні у багатьох викладачів - це колосальна здатність до multitasking (мультизадачності). Студенти можуть одночасно прослуховувати музику, спілкуватися в соціальних мережах, редагувати фотографії, виконуючи при цьому завдання, яке перед ними поставив викладач. Специфіка роботи їхнього мозку - це висока швидкість, відмінна інтерактивність, здатність швидко грати в комп'ютерні ігри і повне несприйняття книг. Але multitasking повністю ослабив дві важливі речі, на яких базується класичне навчання: об'єм уваги і довгострокову пам'ять [4].

Ми повинні враховувати, що сучасний студент не зможе концентруватися, якщо подача навчального матеріалу викладачем $\epsilon$ одноманітною більше, ніж 10-15 хвилин. Головний шлях до мотивації покоління Z - за короткий період надати інформацію, в якій вони побачать очевидну практичну користь для себе. Під час лекції чи аудиторного заняття викладачу слід постійно створювати ідеальне співвідношення між часом подання інформації і іï практичною цінністю. Якщо презентація клінічного випадку проходитиме 3 надто ретельним аналізом карти стаціонарного хворого, анамнезу життя і хвороби, методичним фізичним оглядом, формулюванням складного багатоетапного діагнозу та тривалим вибором варіантів хірургічної тактики - мети клінічного розбору досягнуто не буде. Подача клінічної інформації повинна вкластися в межах 5-7 хвилин і висвітлити основні пункти: паспортні дані, хірургічний діагноз, тактику і метод лікування у даному випадку. Не кожний викладач сприймає такий підхід, вважаючи його прямим шляхом до лікарського анальфабетизму і повної втрати клінічного мислення. Однак це дозволяє студенту, використовуючи тільки короткочасну пам'ять, створити цілісну картину клінічного випадку. Якщо цього досягнуто, наступним етапом $є$ розподіл клінічного аналізу на багато конкретних проблем, кожну з яких студент може вирішити впродовж короткого часу. Це також сприяє формуванню клінічного мислення, однак не в тій формі, до якої звикли лікарі покоління Х чи Y i тим більше - покоління Вaby Boom. Викладач обов'язково повинен досконало володіти інформацією, яка зможе швидко вказати студенту шлях вирішення проблеми. Такий підхід має високу інтенсивність засвоєння знань, однак зворотний зв'язок $€$ низьким (слабкі елементи дискусії між викладачем i студентом). Він $є$ найбільш доцільним при проведенні самостійної аудиторної роботи студента на клінічній лекції.

Покоління Z не сприймає навчальний матеріал, якщо він подається 3 великим обсягом класифікованої інформації. 3 точки зору сучасного студента такі затрати часу для вивчення матеріалу $\epsilon$ дуже нелогічними, і він відмовиться від сприйняття лекції. Якщо ж ця інформація вкрай необхідна, студенти будуть шукати ії в он-лайн джерелах, які часто

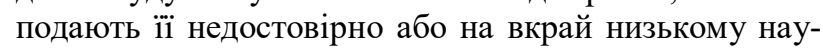
ковому і доказовому рівні, що може спричинити конфлікт між викладачем і студентом під час поточного чи підсумкового оцінювання знань. Сучасна лекція повинна подавати не стільки саму інформацію, скільки правильні шляхи їі отримання за допомогою цифрових технологій, у ході лекції повинні широко використовуватися короткі мультимедійні презентаційні відео, під час коментування яких викладач повинен подавати важливі аспекти лекційного матеріалу. Необхідно враховувати, що візуальний шлях отримання інформації $\epsilon$ найбільш природним для покоління Z.

Під час проведення практичного заняття викладачу потрібно зосередитися на діалозі. Необхідно чітко проаналізувати пізнавальні інтереси кожного студента і напрацювати спеціальні завдання, які повинні включати сучасні комунікаційні методи та забезпечення педагогічної підтримки. Потрібно врахувати, що завдання, які містять багаторазове повторення однієї і тієї ж тези, або ж будуть вимагати занадто грунтовного звернення до попередньо пройдених тем, скоріше всього, не будуть виконані. Потрібно продумати способи мотивації і варіанти фіксування досягнень. Для сучасного студента важливішим $\epsilon$ короткочасний ефективний результат, а досягнення довгострокової мети (успішна здача модуля) для нього є менш цікавим.

Для ефективної позааудиторної самостійної роботи студентів необхідно у повній мірі використовувати їхню схильність до соціалізації в соціальних мережах. Слід широко застосовувати спеціальні технології, які допомагають організувати процес вільної комунікації та обміну думками (Facebook, Viber, Watsap та ін.). Викладач повинен виступати модератором групи, посередником, який встановлює відношення між студентами, однак мінімально впливає на шляхи реалізації рішення, що дозволяє отримати високий зворотний зв'язок.

Підсумовуючи вищевикладене, стає зрозумілим, що процес викладання такої практичної дисципліни як хірургія повинен базуватися на абсолютно нових підходах, відмінних від тих, які були 1020 років тому. Викладач повинен враховувати соціальні й психологічні аспекти життя покоління Z i створювати гнучку індивідуалізовану систему викладання, абсолютно відмінну від тієї, за якою навчали його. Можливо, вона не завжди буде зручною для педагога, однак дозволить створити добрий комунікативний зв'язок між ним і студентами, що дозволить досягнути основної мети навчання. 


\section{Висновки:}

1. Для ефективної самостійної роботи студентів необхідно повною мірою використовувати схильність до соціалізації в соціальних мережах.

2. Слід широко застосовувати спеціальні технології, які допомагають організувати процес вільної комунікації та обміну думками, у яких викладач повинен виступати модератором групи, посередником, який встановлює відношення між студентами 3 мінімальним впливом на шляхи реалізації рішення, що дозволяє отримати високий зворотний зв'язок.

\section{References:}

1. Howe Nei, Strauss William. Generations: The History of America's Future, 1584 to 2069. New York: William Morrow \& Company. 1991; ISBN 978-0-68811912-6.

2. Kamahl TR. Secondary teachers' perceptions toward school leadership: A generational divide? Political SciencePublished. 2017. DOI: 10.4226/66/ 5a9dba2d3361c

3. Ting H, de Run EC. Generations $X$ and $Y$ attitude towards controversial advertising. Asian Journal of Business Researchю 2012; 2:18-32.

4. Meeks MD, Williams F, Knotts TL, James KD. Deep vs. Surface Learning: An Empirical Test of Generational Differences. International Journal of Education and Research. 2013; 1(8):1-16.

\section{УДК [616-08-059 + 615.825]: 378.096 \\ ОСОБЕННОСТИ ПРЕПОДАВАНИЯ МОДУЛЯ «ХИРУРГИЯ» С УЧЕТОМ ТЕОРИИ ПОКОЛЕ- НИЙ STRAUSS-HOWE}

\author{
С.С. Снижко ${ }^{1}$, С.А. Кримець ${ }^{2}$
}

\author{
${ }^{1}$ Ивано-Франковский национальный медицинский \\ университет, кафедра хирургии №2 \\ и кардиохирургии, \\ 2. Ивано-Франковск, Украина, \\ ORCID ID: 0000-0001-5418-7825, \\ e-mail:snizhko.s@bigmir.net; \\ ${ }^{2}$ Ивано-Франковский нацииональный медицинский \\ университет, кафедра хирургии №1, \\ 2. Ивано-Франковск, Украина, \\ ORCID ID: 0000-0002-5098-553, 6 \\ e-mail:skrymets80@gmail.com
}

Резюме. В статье изложены основные подходы к принципам обучения модуля «Хирургия» студентов медицинских факультетов IV и V курсов высших учебных медицинских заведений с позиций теории поколений Strauss-Howe. Современное преподавание должно учитывать психологические особенности людей, родившихся после 1996 года: зависимость от цифровых технологий и восприятия информации путем короткой и яркой подачи. Современный студент обладает очень полезными когнитивными навыками - это колоссальная способность к multitasking (мультизадачности). Специфика работы их мозга - это высокая скорость, отличная интерактивность, способность быстро играть в компьютер- ные игры и полное неприятие книг. Ho multitasking полностью ослабил две важные вещи, на которых базируется классическое обучение: объем внимания и долгосрочную память. Процесс преподавания такой практической дисциплины как хирургия должен базироваться на совершенно новых подходах, отличных от тех, которые были 10-20 лет назад. Современный студент не сможет концентрироваться, если подача учебного материала преподавателем является однообразной больше, чем 10-15 минут. Главный путь к мотивации поколения $Z$ - за короткий период предоставить информацию, в которой они увидят очевидную практическую пользу для себя. Во время лекции или аудиторного занятия преподавателю следует постоянно создавать идеальное соотношение между временем подачи информации и ее практической ценностью. Подача клинической информации должна уложиться в пределах 5-7 минут и осветить основные пункты: паспортные данные, хирургический диагноз, тактику и метод лечения в данном случае. Преподаватель должен учитывать социальные и психологические аспекты жизни поколения $\mathrm{Z}$ и создавать гибкую индивидуализированную систему преподавания, совершенно отличную от той, по которой учили его. Она не всегда будет удобной для педагога, однако позволит создать хороший коммуникативную связь между ним и студентами, позволит достичь основной цели обучения.

Ключевые слова: поколение Z, преподавания, хирургия.

\section{UDC [616-08-059+615.825]: 378.096 \\ FEATURES OF TEACHING THE SURGERY MODULE, TAKING INTO ACCOUNT STRAUSS- HOWE GENERAL THEORY}

\author{
S.S. Snizhko ${ }^{1}$, S.A. Crimets ${ }^{2}$ \\ ${ }^{I}$ Ivano-Frankivsk National Medical University, \\ Department of Surgery No. 2 and Cardiac Surgery, \\ Ivano-Frankivsk, Ukraine, \\ ORCID ID: 0000-0001-5418-7825, \\ e-mail:snizhko.s@bigmir.net; \\ ${ }^{2}$ Ivano-Frankivsk National Medical University, \\ Department of Surgery №1, Ivano-Frankivsk, Ukraine, \\ ORCID ID: 0000-0002-5098-553, \\ e-mail: skrymets80@gmail.com
}

Abstract. The article presents the basic approaches to the principles of teaching the module "Surgery" to students of medical faculties of IV and V courses of higher educational institutions from the standpoint of Strauss-Howe generation theory. Modern teaching should take into account the psychological characteristics of people born after 1996: the dependence on digital technology and the perception of information through short and vivid presentation. The modern student has very useful cognitive skills - a tremendous ability to multitasking. The specifics of their brains are high speed, excellent interactivity, the ability to play computer games quickly, and complete rejection of books. But multitasking has 
completely weakened two important things that underpin classic learning: attention span and long-term memory. The process of teaching such a practical discipline as surgery should be based on completely new approaches, different from those that were 10-20 years ago. The modern student will not be able to concentrate if the teaching material is unanimous for more than 10-15 minutes. The main way to motivate Generation $\mathrm{Z}$ is to provide information in a short period in which they will see the obvious practical benefit to themselves. For the modern student, more important is the short-term effective result, and the achievement of a long-term goal (successful delivery of the module) is less interesting for him. During the lecture or class, the teacher should constantly create the perfect balance between the time of presentation of information and its practical value. The submission of clinical information should be within 5-7 minutes and highlight the main points: passport data, surgical diagnosis, tactics and treatment in this case. During the practical training, the teacher should focus on the dialogue. It is necessary to clearly analyze the cognitive interests of each student and to develop special tasks, which should include modern communication methods and providing pedagogical support. The teacher must have a thorough knowledge of the information that can quickly indicate to the student how to solve the problem. This approach has a high intensity of learning, but the feedback is low (weak elements of discussion between teacher and student). It is most appropriate when conducting a student's independent classroom work in a clinical lecture. The teacher must take into account the social and psychological aspects of the life of Generation $\mathrm{Z}$ and create a flexible individualized teaching system that is completely different from the one taught. It will not always be convenient for the teacher, but will create a good communication link between him and the students, which will achieve the main goal of learning. Contemporary lectures should not provide as much information as the correct ways of obtaining them through digital technologies, and short multimedia presentation videos should be widely used in the course of the lecture, during which the lecturer should submit important aspects of the lecture material. It should be borne in mind that the visual way of obtaining information is the most natural for Generation $Z$. For effective independent work of students it is necessary to make full use of the tendency to socialization in social networks. Special technologies should be widely used to help organize the process of free communication and the exchange of views in which the teacher should act as a group moderator, a facilitator who establishes a relationship between students with minimal impact on ways to implement a solution that allows for high feedback.

Keywords: generation Z, teaching, surgery.

Стаття надійшла вредакцію 21.02.2020 р. 